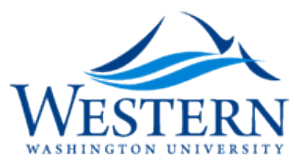

Western Washington University

Western CEDAR

Anthropology Faculty and Staff Publications

Anthropology

$2-1989$

\title{
Moses, Oedipus, Structuralism, and History
}

Robert C. Marshall

Western Washington University, robert.marshall@wwu.edu

Follow this and additional works at: https://cedar.wwu.edu/anthropology_facpubs

Cart of the Anthropology Commons

\section{Recommended Citation}

Marshall, Robert C., "Moses, Oedipus, Structuralism, and History" (1989). Anthropology Faculty and Staff Publications. 1.

https://cedar.wwu.edu/anthropology_facpubs/1

This Article is brought to you for free and open access by the Anthropology at Western CEDAR. It has been accepted for inclusion in Anthropology Faculty and Staff Publications by an authorized administrator of Western CEDAR. For more information, please contact westerncedar@wwu.edu. 


\section{CHICAGO JOURNALS}

Moses, Oedipus, Structuralism, and History

Author(s): Robert C. Marshall

Source: History of Religions, Vol. 28, No. 3 (Feb., 1989), pp. 245-266

Published by: The University of Chicago Press

Stable URL: http://www.jstor.org/stable/1062749

Accessed: $21 / 10 / 2014$ 16:27

Your use of the JSTOR archive indicates your acceptance of the Terms \& Conditions of Use, available at

http://www.jstor.org/page/info/about/policies/terms.jsp

JSTOR is a not-for-profit service that helps scholars, researchers, and students discover, use, and build upon a wide range of content in a trusted digital archive. We use information technology and tools to increase productivity and facilitate new forms of scholarship. For more information about JSTOR, please contact support@ jstor.org. 


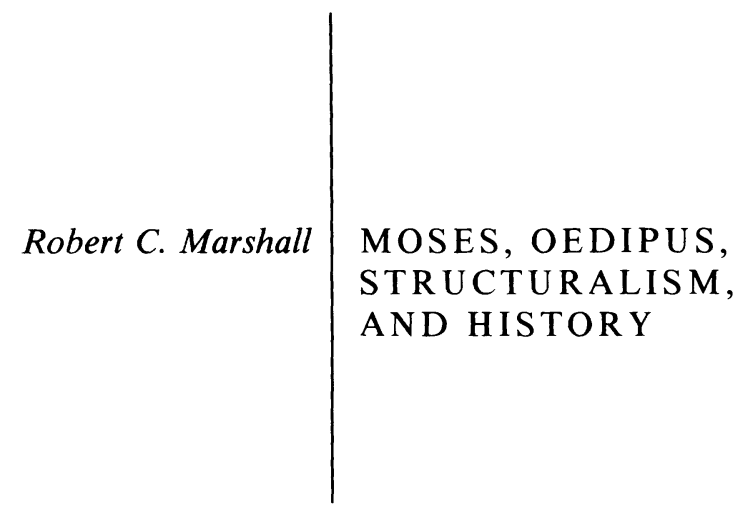

Myths emerge in consciousness as solutions to problems of existence among those who find it worthwhile to reproduce those myths. The many variants that are the myth, appearing as combinations and recombinations of diverse and changing components in an unchanging structure of relationships, are as many possible solutions, more stimuli still for their audiences' imaginations. By the end of the fifth century B.C. for both the Athenians and the Israelites the paramount problem had become the preservation of a form of suzerainty, sociocultural continuity without sovereignty.

The myths of Oedipus and Moses converge in their structures at this historical moment on one particular solution to this problem. The answer both give, in the languages and symbols of their respective cultures, is "deliberately and self-consciously preserve and reproduce the culture that bears this myth. Value this culture more than a share in your conqueror's sovereignty." They leave implicit the continuation "If you do so, someday you may be able to regain your own sovereignty." It is my purpose to show by means of parallel analyses

I thank Michael Carroll and Robert Stoops for their comments, criticisms, and encouragement.

O 1989 by The University of Chicago. All rights reserved. $0018-2710 / 89 / 2803-0003 \$ 01.00$ 
of these two myths how they achieve the effect they aim at through the structuring of complex symbols in narrative form.

It is methodologically necessary at this point to emphasize the magnitude of the conception of Claude Lévi-Strauss in his resolution to "define the myth as consisting of all its versions; or to put it otherwise, a myth remains the same as long as it is felt as such." It is necessary to add the implied continuation of his sentence: "by those who feel the myth important enough to reproduce it."

Lévi-Strauss's conception of the integrity of the myth is the exact counterpart in cultural analysis to that which allowed Charles Darwin to banish the concept of "essentialism" forever from biological thought, and later biologists to define the species as all of the variant individuals able to reproduce fertile offspring among themselves. Darwin, however, founded modern biological science on the further observation that individual variation resulted in the changed form of the species in time and that this was precisely because some variations were better able than others to reproduce themselves in changed environments.

After the wide rejection of his analysis of the Oedipus myth, ${ }^{2}$ LéviStrauss returned to the world of his earlier anthropological experience, $^{3}$ that of the Indians of South America, a world in which environmental change was not easily perceived and could not be permanently recorded, a world without its own history, without linear time, without change, without writing. He did so to demonstrate the unchanging structure of myth, but in doing so he could examine mythic variation in its geographic distribution only. Darwin examined organic variation in space and in time and consequently was able to show why some variations succeed where others fail. Structural analysis has been unable to address theoretically the issue of the success or failure of mythic variants. This methodological point must be stressed precisely because the myths of Oedipus and Moses are supremely successful, if the measure of success for a myth is its capacity to induce its audience to reproduce it faithfully over time, its capacity to reproduce its audience.

In the attempt to come to a fuller understanding of these myths in relation to their underlying problem, it is most fortunate that among all Western myths, with the exception of the Christ myth, these two have been most thoroughly examined. Both myths seem to have originated roughly toward the end of the second millennium B.C. The

\footnotetext{
I Claude Lévi-Strauss, "The Structural Study of Myth," in Myth, a Symposium, ed. Thomas Sebeok (Bloomington: Indiana University Press, 1955), p. 92.

2 Jean Pierre Vernant, "From Oedipus to Periander: Lameness, Tyranny, Incest in Legend and History," Arethusa 15 (1982): 19.

${ }^{3}$ See Claude Lévi-Strauss, The Raw and the Cooked (New York: Harper, 1969).
} 
forms in which we possess them are quite contemporary products. ${ }^{4}$ Both achieved something akin to canonic status around 400 B.C., Moses a few decades earlier than Oedipus, and under similar historical impetus. ${ }^{5}$ The forms we possess preserve evidence of the myths' historical development and reevaluation. ${ }^{6}$ It is because of this preservation and scholarship that we are able to see in both of these myths how components produced for one end at an earlier time came to be used for another end at a later time.

4 While there are common elements in these myths, it is unlikely that either myth was patterned after the other. Both participate in a general Eastern Mediterranean-Middle Eastern knowledge, but Greek and Jewish cultures came into direct contact only in the Hellenistic period and then in a decidedly antagonistic way. This question is discussed by Martin Hengel in Jews, Greeks and Barbarians (Philadelphia: Fortress, 1980), pp. 11-12.

5 It would be misleading to suggest that the myth of Oedipus, even the plays of Sophocles, had an official status like that of the Moses narrative. Greek religion was not like Jewish religion. As Jean Pierre Vernant observes in Myth and Society in Ancient Greece (Atlantic Highlands, N.J.: Humanities Press, 1980), p. 205, the myth of Oedipus "is not a dogma with a form strictly fixed once and for all because it represents the basis for an obligatory belief," since it was not the nature of Greek religion to produce such texts $\rightarrow$ C. Jan Swearingen points out in "Oral Hermeneutics during the Transition to Literacy: The Contemporary Debate," Cultural Anthropology 1 (1986): 150, some Greek religious traditions even explicitly forbade the production of such texts. Yet Lowell Edmunds, in Oedipus: The Ancient Legend and Its Later Analogues (Baltimore: Johns Hopkins University Press, 1985), p. 48, does not hesitate to refer to the "now canonical Sophoclean version of the Oedipus story." At least some of the fifth-century Attic tragedies had something like canonic form by the fourth century: ca. 330 B.C. Lycurgus, "a leading Athenian statesman, regulated performance [of revivals of the fifth-century plays] by requiring actions to follow an official text deposited in state archives in order to prevent [performers] from interfering with the dramas they produced," Ruth Scodel remarks in Sophocles (Cambridge, Mass.: Harvard University Press, 1984), p. 124. This sense of the need for preservation rather than free reproduction of the underlying mythical materials arose from the changed conditions of dramatic production: Eric Havelock, in The Literate Revolution in Greece and Its Cultural Consequences (Princeton, N.J.: Princeton University Press, 1982), p. 311, points out that while even in the apparently highly personal art of Oedipus the King, "the poet, in the words of Aeschylus, is still the voice of what is 'useful' to the community," he continues with the observation that later "family matters, rather than civic education, became the business of the stage ... and the whole emphasis ... shifted from tradition to entertainment. This was not done ... . earlier than the fourth century" (Havelock, p. 310). It is Havelock's thesis that this transformation is directly related to the shift from purely oral to written communication. But we must find room in our conception if not in our language for the idea that the plays of Sophocles, if not the underlying myth of Oedipus, have a particular and possibly unique position in Western culture and had so in Athens, even if we choose to reserve the word "canon" for other types of texts.

6 Vernant suggests a useful distinction between "version" and "variant": when myths contain evidence for historical depth, we should call them versions; otherwise, call them variants. Because the present essay compares two myths from different regions and cultures but which converge on a formal framework and purpose (see Walter Burkert, Structure and History in Greek Mythology [Berkeley and Los Angeles: University of California Press, 1979], p. 18) at approximately the same historical moment, I shall treat these myths as variants of each other, each composed of now only partially recoverable versions. For example, that Homer left Oedipus on the 


\section{MYTHIC STRUCTURE}

Myths are narratives composed of three interconnected structures. First, a sequential ordering of action by episode that captures and focuses the attention and anticipation of the audience appears as the surface of the myth, the story that it tells. At the deepest level, the

throne of Thebes is well known, but only recently has Edmunds argued persuasively for the very late (fifth century B.C.) addition of the Sphinx episode to the Oedipus myth (see Lowell Edmunds, "The Sphinx in the Oedipus legend," in Oedipus: A Folklore Casebook, ed. Lowell Edmunds and Alan Dundes [New York: Garland, 1983], p. 148, and Oedipus: The Ancient Legend, p. 33). G. S. Kirk concludes in the Nature of Greek Myths (Harmondsworth: Penguin, 1974), pp. 163-64, that although the Oedipus legend has Mycenean roots, it becomes socially important only later and that "his really mythical essence is contained in Sophocles' plays: his murder and marriage, his selfdiscovery, his agony and blinding, his miraculous assumption in the grove of Colonus near Athens. Most of this is likely to be comparatively recent in anything like that form." Propp and others interested in the Oedipus legend tend to see Sophocles' two Oedipus plays as "an organic whole" (see Vladimir Propp, "Oedipus in the Light of Folklore," in Edmunds and Dundes, eds., p. 115; see also Edmunds, Oedipus: The Ancient Legend, p. 39), yet some question remains of Sophocles' contribution of detail, e.g., at the end of Oedipus's life: Charles Segal asserts in Tragedy and Civilization: An Interpretation of Sophocles (Cambridge, Mass.: Harvard University Press, 1981), p. 482 , "Still, we cannot be sure that the intimate linking of Oedipus' grave with the grove of the Eumenides antedates Sophocles," and "thus some scholars argue that the location of the tomb in the sanctuary of the Furies was Sophocles' invention. . . But there were probably several variant legends in Sophocles' time about Oedipus' place of burial.... One of these may have included burial in the Furies' grove. If that is Sophocles' addition, it reveals again the boldness and rightness of his mythopoeic imagination" (Segal, p. 483). The compositional status of the Moses story is much the same. It is well known that many sources have gone into both the biblical and extrabiblical narrative, but it is not necessarily clear at each point which lines belong to which sources: "Exodus is so complex that it is impossible to assign material to sources with any degree of confidence" is the conclusion of Alberto J. Soggin in his Introduction to the Old Testament (Philadelphia: Westminster, 1976), p. 103. This seems especially true of much of the sixth-fifth-century "Priestly" or "P" source, and there are many problems associated with the separation of the much earlier $\mathrm{J}$ and $\mathrm{E}$ materials (see Brevard S. Childs, The Book of Exodus [Philadelphia: Westminster, 1979], pp. 165-66). It is sufficient here to indicate some of the complexity of the narrative and its internal evidence: "The presence of striking doublets (cf. Meribah, Ex. 17//Num. 20; manna, Ex. 16//Num. 11) indicates the present arrangement reflects a complex history of traditional and literary development.... There is an increasing tendency within the Old Testament to unify the material within a larger conceptual framework and see [the wilderness wanderings tradition] as a sharply defined period within the nation's history" (Childs, pp. 254-55). Later redactors were unable to successfully weld the different wilderness traditions into a seamless whole. The events that occur between Egypt and Sinai (Exodus 16-18) are simply repeated with editorial changes that link them to Kadesh (see Numbers 10-20 for this material; and see Norman K. Gottwald, The Hebrew Bible: A Socio-literary Introduction [Philadelphia: Fortress, 1985], p. 200, for commentary). For both traditions, Greek and Jewish, I follow the view of Edmund Leach, "Why Did Moses Have a Sister," in Structuralist Interpretations of Biblical Myth, ed. Edmund Leach and D. A. Aycock (Cambridge: Cambridge University Press, 1985), p. 35, "that none of the stories recorded in the Bible ... are at all likely to be true as history," and Havelock, that classical history is not conceived as matter for modern reportage and interpretation, but for "redrafting within the parameters of the writer's own preconceptions, who however assumed a continuity between himself and his subject and identified with it" (p. 24). 
paradigmatic structure models and mediates the contradictory experience of the audience, allowing the audience to reenergize its behavior on the basis of the myth's representations of relevant parallels. Linking these two structures, formed on diachrony and synchrony, respectively, is the third level of structure, which presents the action in images of immediate and concrete sense perception as "statements about the world to establish relations between categories,"7 and thus clothes the entire narrative with the appearance of utter "factuality." The present analysis will proceed through the narrative structure to the myths' characteristic symbolisms and conclude with their paradigmatic structure.

\section{NARRATIVE STRUCTURE}

The narrative structure, the story pattern, of the myths of Oedipus and Moses is, above all else, "a kind of biography, a pattern of life." 8 It presents the hero's life in three major parts: birth and adoption, transition to adulthood, and maturity and death. Each of these three major sections is itself formed of three sections. By means of the complex relations established between these segments, audience expectations are aroused, confounded, and alternative expectations substituted. In outline, the following pattern is the structure of the plot of both myths:

I. Birth and adoption

A. A child already condemned to death is born

B. The child is abandoned, then rescued

C. The child is adopted and raised with an altered identity

II. Coming of age

A. The youth's adoptive identity breaks down

B. He becomes a homeless homicide

C. He passes the test of a supernatural being to regain his rightful identity

III. Maturity and death

A. He quickly performs the deeds for which he is famous

B. He is exiled to the wilderness for the rest of his long adult life

C. He is judged and dies, leaving a legacy and receiving a reward, but the location of his grave is forgotten by posterity

The hero who lives this life is characterized by an unusual name and a stigma from the time, and as a result, of his exposure. His unusual name, in conjunction with his defect and interpreted as a

7 Dan Sperber, Rethinking Symbolism (Cambridge: Cambridge University Press, 1975), p. 7.

8 Edmunds, Oedipus: The Ancient Legend, p. 6. 
pun, indicates his major activity in the myth. While other aspects of his identity change from segment to segment throughout the myth, the name and stigma remain constant.

\section{SYMBOLIC STRUCTURE}

The symbolic structure gives the narrative structure its characteristic expression, creating variants. It is at this level that the myths of Oedipus and Moses appear maximally different, as reciprocal inversions and the products of very different cultural traditions. The narrative is placed in either the positive or negative mode at this level of structure. ${ }^{9}$ The selection of symbols that "flesh out" the narrative action is controlled between the requirements of the sequence of events and those of the paradigmatic structure.

The symbolic mechanism of this level does not structure action or timeless verities but induces the audience to reflect on its own experience in light of the myth's concrete representations of the narrative action and its consequences in terms of underlying cultural categories. Much of the power and relevance of these two myths is the result of the consistent and imaginative application of this mechanism to categories so fundamental that they are shared by both Greek and Israelite culture of the period and later, as well as our own and perhaps to some degree all state-level societies.

The symbolic mechanism first represents a pair of categories as a reciprocal metaphor, " $A$ is $B, B$ is $A$." Each category is then characterized by (at least) two attributes, allowing the sufficient differences between the two categories to be emphasized. This step takes the intermediate form " $A$ is $a_{1}$ and $a_{2} ; B$ is $b_{1}$ and $b_{2}$," and takes the final form " $a_{1}: a_{2}:: b_{1}: b_{2}$," so that the basic metaphoric relation of the categories $A$ and $B$ is preserved. This is the form of everyday life in symbolic representation.

These conventional pairs of attributes are then recombined to produce two new imaginary categories with the elaborated form " $a_{1}: b_{1}:: a_{2}: b_{2}$." The pairs that result from this recombination of attributes, " $a_{1}+b_{1}$ " and " $a_{2}+b_{2}$," respectively, form two new conceptual objects that, although they may exist only in the imagination, are still in the same reciprocally metaphoric relation.

Although these two new conceptual objects may not even have labels (and this makes it extremely difficult for the audience/analyst to raise these objects to consciousness), the symbolic action of the narrative generates events in which these new objects participate and the consequences of which must be evaluated relative to the old,

9 Ibid., p. 35. 
everyday metaphor. The audience can then judge whether those consequences are preferable to the results produced in everyday life, results the audience habitually expects.

An audience accepts the premises of a plot, its founding metaphors, and symbolic structure, "to see how it all turns out." For a myth to be successful in this effort, it must help the audience accept that such new conceptual objects allow the minor contradiction in the paradigmatic structure to better seem to resolve the major contradiction the myth seeks to defuse. Thus the audience will be freed of the debilitating effects of contradiction and be enabled to undertake further action toward the solution to its existential problem. In the myths of Oedipus and Moses the movement of symbolic action is controlled for maximum contrast by means of the sequential logic of contrary motion. ${ }^{10}$

Each major segment presents and then undermines one central conventional metaphor and structures the symbolic action of the segment to commit the audience to a preference for the outcome of the action based on new but nameless conceptual objects in the same metaphoric relation. The "birth and adoption" segments undermines the metaphor "place = society," the "coming of age" segment undermines the metaphor "identity = behavior," and the "maturity and death" segment undermines the metaphor "power = place." Because of limitations of space it is not possible to do justice to the complexity of relations and wealth of potentially evocative material in the symbolism of all three segments for both myths. Neither, for the same reason, is it necessary to review here the contents of these two widely known and easily accessible myths. ${ }^{11}$ The following section will examine the operation of the symbolic mechanism in each of the three major segments of these myths.

Birth and adoption. The major goals of this segment are, by structural level, (1) to bring the hero into the world and involve him in action that interests the audience in his fate; (2) to ground this action in symbolism that undermines categories of daily life while not

10 Jean Pierre Vernant, in "Ambiguity and Reversal: On the Enigmatic Structure of Oedipus Rex," in Tragedy and Myth in Ancient Greece, ed. Jean Pierre Vernant and Pierre Vidal-Naquet (Atlantic Highlands, N.J.: Humanities Press, 1981), p. 110, has suggested that the tragedy of Oedipus has as its structural foundation "the purely operational schema of reversal, a rule of ambiguous logic. But the tragedy gives content to this form." We must be careful to distinguish between reversal as a logical operation behind the action and "reversal" as a theme of the story. If there are no constant elements, we cannot say what is reversed and what merely changed or altered.

11 I have drawn primarily on Greek Tragedies, vols. 1 and 2, ed. David Green and Richmond Lattimore (Chicago: University of Chicago Press, 1960), for the Sophoclean account of the myth of Oedipus, and the Revised Standard Version of the Holy Bible for the canonic Moses myth. 
alienating the audience from the myth's alternative representation of experience; and (3) to provide the hero with an identity and a problem, such that "identity = problem."

The child is, from the very beginning, put in a "bind." The audience is encouraged to accept that even an altered identity is better than death. The metaphor "place = society" is undermined to give the following result:

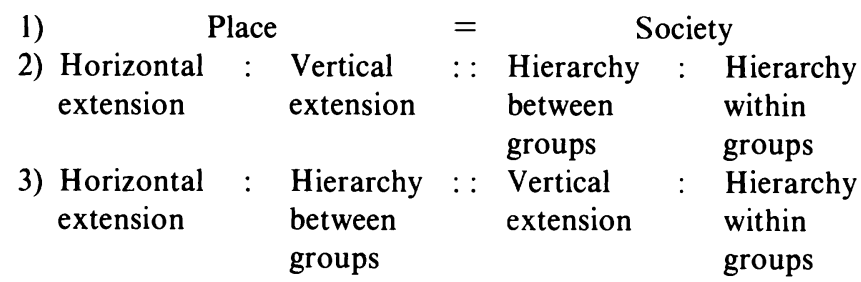

The "novel" conceptual objects created by this recombination of attributes are not especially novel within fifth-century B.C. Athenian and Israelite experience. They are almost trivial insofar as this new metaphor is easily comprehended on the basis of daily life. But that is its contribution to this segment, to be relatively unobtrusive and yet found a pattern for future development in the myth. The audience is thus allowed to focus on what is happening to the child, to accept the predicament of the stigmatized child as possible, if not probable, and to prefer that the child live, even with an altered identity.

In the course of the action, the child is passed through all four attributive dimensions, only to end up at much the same place he started. Throughout the segment, inversion of sign and function within episodes is strictly maintained between myths. This is possible because these component materials were so widely distributed in the Near East-Eastern Mediterranean region at that time.

The infant should not live but does. He is then abandoned by a parent, rescued by a person of opposite status and different ethnicity, and comes to rest in the hands of a person of similar status and ethnicity to that of his parent. Oedipus is exposed by his father on Mount Citheron to kill him. Moses is concealed by his mother on the Nile to save him. Oedipus is taken from Thebes by Laios, is rescued by a servant/slave/shepherd from the mountain, and taken further to the king of Corinth. ${ }^{12}$ Moses is hidden in the bulrush ark, is rescued

12 "Shepherds in Thebes were an ethnically distinct autochthonous group, repressed by the Theban aristocracy: the shepherd is thus a prototypically 'marginal' character"; Terence Turner, "Oedipus: Time and Structure in Narrative Form," in Forms of Symbolic Action, ed. Robert F. Spencer, Proceedings of the 1969 annual spring 
by the princess, and returned to his mother. ${ }^{13}$ All four dimension are used to alter, through the sequence of action, the child's identity, which remains the same and yet is not the same. His new identity may be adequate to the passive condition of the child, but it will not sustain the activity of an adult. People who would not do so for the adult show the child compassion. But at the same time, the childadult relation is still hierarchical. The potential relation within adult experience that is completely suppressed in this representation is "equality."

The conceptual objects involved are easily assimilated to daily thought. The form in which the action is cast is also easily encompassed by the audience's normal experience. This form is the wellknown "rite of passage" ritual, the normal function of which is to translate an individual across social identities such that the link between the old and the new identities is made explicit by the rituals. In these myths this function is reversed. While preserving the life of the "child returned from the dead," 14 the ritual is performed to sever and hide, to confuse, the continuity of the child's identity. Consequently, the child cannot "known his place," physically or socially, and the audience can only recognize him when he appears again by his unusual name and his stigma.

Coming of age. The metaphor undermined in this segment is "identity = behavior." The following formula structures the categorical relations symbolized in this segment of the myths:

\begin{tabular}{lllll} 
Id) Idity & $=$ & \multicolumn{2}{c}{ Behavior } \\
2) Knowledge $:$ Appearance & $:$ : & Compulsion $:$ Will \\
3) Knowledge $:$ Compulsion & $:$ : & Appearance $:$ Will
\end{tabular}

At the end of the previous segment the child had been given a stigmatized identity. In this second segment the hero, as he becomes an adult, must act on the basis of this stigmatized identity. In the metaphor that structures this segment, a child should grow up "knowing his place," he will be consistent both inside (knowledge) and out (appearance), and he will "will" to do as he "must." Correct and conventional behavior is expected to flow from correct identity. As

meeting of the American Ethnological Society (Seattle: University of Washington Press, 1969), p. 39. Turner cites here W. K. Lacey, The Family in Classical Greece (Ithaca, N.Y.: Cornell University Press, 1968), p. 53.

13 The change in Moses' mother's status is especially marked through the princess' payment of money to her to nurse her own child at Exod. 17:9. By this act she is and is not his own mother, and the princess can later claim him.

14 Leach and Aycock, eds. (n. 6 above), p. 54. 
cracks appear in the youth's identity where he was raised, audience expectations are reinforced by action that is merely the converse of the conventional view: a flawed identity will produce incorrect behavior. It does, and the youth flees the place in which his flawed identity is known. The episode then ends with action that reverses audience expectations by asserting that in a different place the flawed identity will, with the intervention of the divine, lead to correct behavior and the hero's repossession of his rightful and rectified original identity. This turn of events is plausible to an audience because the symbolic action encourages it to accept as fact that while one might will appearances, knowledge (= divinity) is compelling.

Oedipus begins in doubt and acquires confidence as he proceeds. Moses begins willfully and grows more doubtful and passive as events unfold. Oedipus leaves Corinth to avoid killing his father and then, for the sake of mere appearances, kills his "real" father willfully and justifiably, but in ignorance. Moses, in the confusion of his identity, absurdly (if justifiably from the Israelite point of view) kills an Egyptian and then flees, only to himself acquire a foreign wife (by means of his passive appearance as an Egyptian) and a son (about whom the myth remains otherwise silent). Both heroes then, in the place to which they have fled, encounter a supernatural being.

The encounter of the hero with the supernatural being is central to both myths, their turning points. ${ }^{15}$ Oedipus tells the sphinx who he, Oedipus, is in the most general terms, "man," but which answer, in the terms of the riddle, does not apply to him alone: "limping on two" is not part of the riddle. Yehweh tells Moses alone who he, Yehweh, is in the most specific terms as a deity, but in self-referential and, so, riddle-like language with regard to his specific name, "I AM," and Moses attempts to convince Yehweh that Yehweh's injunction does not apply to him, Moses. Through this contact with the supernatural, Oedipus transmits and Moses receives "knowledge." This knowledge is utterly compelling and results in the death of the Sphinx and life/death of Thebans, and the "life" of Yehweh and life/death of the Israelites.

Both heroes also gain, as result of this encounter, their "true" identities and the capacity to do that which they do first as adults. But while the heroes ultimately agree with regard to their characteristic deeds that "I have not done them of my own mind,"

15 See Terence Turner, "Narrative Structure and Mythopoesis," Arethusa 10 (1977): 156-57, on Oedipus. All commentators are agreed on the centrality in the tradition concerning Moses' meeting with Yehweh in Midian.

16 Numbers 16:28. 
acts of negative effect as a victim of appearances and Moses is compelled to act positively from knowledge.

Maturity and death. This final segment undermines the metaphor "power = place." In the heavily overdetermined conventional view of sovereignty in these myths, the concept of "place' is used to totalize relations of domination and geographic distribution within and between societies. Power is seen to emanate as a thing in itself and of its very nature from the highest "place" at the center of a society outward and downward to dominate geographically dispersed "nations" and "peoples," like a beacon or tidal wave, becoming less intense as the distance from its source increases. This animatistic view of power as an attribute, a cause rather than a consequence, dominates in Western culture still. ${ }^{17}$

This metaphor is opened to reconceptualization and reformulation in the following manner:

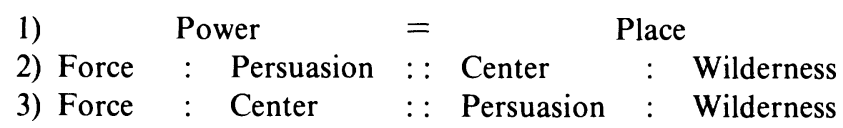

The symbolic action of this segment opens with Oedipus as a conventional sacred king, but his claim to his title is overdetermined. He has both succeeded to his throne and won it by trial. The first act he must perform as the sort of king he thinks he is, the latter type, is the one act no king of the former sort, nor anyone else, may perform, bridging the single most important discontinuity that all societies and families must maintain, mother-son marriage and reproduction.

Moses is as far from sacred kingship as the adopted son of Pharaoh's daughter can be, yet he returns to Egypt after an enormously overdetermined struggle with Yehweh, and in doing so creates, after another enormously overdetermined struggle, that one break in the hierarchical relations of ethnicity at the center that no dominant society can allow, a successful revolt and departure of slaves.

The effect of Oedipus's act is to Theban society from its point of view as the effect of Moses' act is to Egyptian society from its point of view. But because the story is told by Israelites for Israelites, the sign and function of this act must be inverted. Consequently, it is as implausible that Oedipus is kept or allowed to stay in Thebes (in some variants) after he brings his crimes to light as it is that Moses is kept in the wilderness and not allowed to enter the promised land.

17 Bruno Latour, "The Powers of Association," in Power, Action and Belief, ed. John Law (London: Routledge \& Kegan Paul, 1986), p. 265. 
But while the Oedipus myth now contains no explicit rationale for this variant fact, leaving us to imagine some connection between, say, criminality and sacral kingship, Moses is explicitly refused entry into the promised land at Num. 20:5-13 for performing incorrectly-he uses his rod rather than the spoken word to release water from a rock - the very act in the very form in which he is commanded to perform it at Exod. 17:1-7 and which passage occurs earlier in the narrative. ${ }^{18}$ Oedipus uses coercion at the center to discover the identity of Laios's murderer and is expelled from Thebes. Moses uses force in the wilderness and so is compelled to remain there. It is the task of the symbolic mechanism to have implausible events be taken as facts; the task of the audience is to imagine how and why such things happen.

After wandering in the wilderness virtually all of his adult life (but how long was Moses in Midian, Oedipus in Thebes?) Oedipus, blind and led by one daughter, Moses, visionary and leading a secondgeneration host, come to the end of long lives at the margin between center and wilderness. Oedipus tells others what he and they must do and where he will die. He then slips into oblivion in the sacred grove. ${ }^{19}$ Moses is told what he and others will do, ascends a mountain for a view of the promised land, and then dies.

18 A significant portion of my argument rests on the general order in which some variants were introduced into the tradition. It is germane to my hypothesis that the $\mathbf{P}$ source condemn Moses for being insufficiently spiritual and that this requirement could be met by understanding him to use force when he should speak with regard to the (at best) "highly improbable" as a category of experience. In understanding the Moses material in this way, I follow Robert Pfeiffer, Introduction to the Old Testament (New York: Harper, 1948), pp. 174, 189, with regard to the development of the documentary tradition, that Num. 20:6-12 is generally $P$, but not to include Num. 20:8a, 9 , and 11 , which is E. It is Pfeiffer's contention that Moses' rod is the contribution of the Elohist. I find support for this understanding in Martin Noth's somewhat different view in Exodus: A Commentary (Philadelphia: Westminster, 1962), pp. 146-47, that Num. 20:1-13 is generally E reworked by the Priestly tradition: "The change from striking with the rod (Exodus 17) to an 'address' can be understood as a conscious spiritualization of the action by P." In Noth's view, "for P the personal guilt of Moses . . . seemed essential to explain Yehweh's harsh judgement" (Noth, p. 147). Soggin (n. 6 above), p. 107 is somewhat more cautious in assigning sources, identifying Exod. 17:1 ff. to E and Numbers 20 to $P$ only in part. Gottwald (n. 6 above), pp. 182-83, on the other hand, liberally asserts Exod. 17:2-7 to be all J, and Num. 20:1-13 to be all E. All that is essential to my argument among these possibilities is that (1) Moses be denied entry into the promised land for striking rather than speaking to the rock. Numbers $20: 8$ and 12 is explicit on this point. And (2), that the sense of these two verses be the later rather than the earlier tradition. I have discovered no commentators in dispute on either of these points, which is by no means to say that in the vast secondary literature there is not at least one reasoned counterclaim.

19 The Athenians identified the Eumenidies with the Furies, the All Seeing Ones, which chthonic deities were charged with avenging parricides (Edward Tripp, The 
The hero's grave gains relevance as the marker of the margin between center and wilderness. The exact location of the grave is known to have been forgotten and so cannot itself be used to form a center, but it is known and remembered that his grave is neither in the wilderness nor in a center. The unmarking of the hero's grave thus permanently marks out the existence of the two kinds of "place," without indicating explicitly where that boundary is.

The biography of the hero completes a passage. Oedipus begins life on a mountain condemned to die because he has the capacity to destroy a state through the confusion of categories, and he ends life below ground with the capacity to preserve one state and destroy another by marking the edge between the center and the wilderness with his unmarked grave. Moses begins life in a (casket-like) ark below ground level with the potential to destroy a state through force ${ }^{20}$ and ends life on a mountainside with the capacity to mark the edge between center and wilderness with his unmarked grave, and across which the Hebrews can then pass to force a new state into being by destroying existing states.

\section{PARADIGMATIC STRUCTURE}

Symbolic representations do not yield to interpretations as isolated elements; interpretations of single "symbols" are not determinate. ${ }^{21}$ Myths are systems of structured symbolic representations. The relationships among symbolic representations, in the paradigmatic structure of these two myths at least, are also complex, relations between relations. The complex relation of the constant identity of the "stigmatized" hero to the variable aspect of the hero's identity in relation to the supernatural being is the minor contradiction which models and makes possible the resolution of the major contradiction in the myth, that a population can and cannot maintain its integrity without sovereignty. Figure 1 presents the paradigmatic structure of these myths in schematic form.

Meridian Handbook of Classical Mythology [New York: Meridian, 1970], pp. 231-32). Their acceptance of Oedipus into their sanctuary argues at least for some degree of redemption for Oedipus.

20 Exodus 1:19.

$\rightarrow$ R. G. A. Buxton, in "Blindness and Limits: Sophokles and the Logic of Myth," Journal of Hellenic Studies 100 (1980): 31, e.g., suggests that in Greek myths, certain acts often result in blindness, and these acts typically involve the "over-stepping of limits." But alternative interpretations remain possible: Edmunds (Oedipus: The Ancient Legend [n. 5 above], p. 3, n. 8) quotes an equally plausible interpretation: cf. M. Davies, "The End of Sophocles' O.T.," Hermes 110 (1982): 277, n. 24: "Why not say Oedipus loses his eyes to symbolize his lack of insight?" Indeed, why not say both, and more? 


\begin{tabular}{|c|c|c|c|}
\hline Kinship & : Polity & $\begin{array}{c}: \text { Oedipus negates Sphinx } \\
\text { by affirming nonself }\end{array}$ & $:$ Oedipus $=$ "Swollen-foot" \\
\hline Culture & Sovereignty & $\begin{array}{c}: \text { Hero passes test, gains } \\
\text { "true" identity }\end{array}$ & $\begin{array}{l}: \text { Hero }=\text { stigma }+ \\
\text { name } / \text { pun }+ \text { function }\end{array}$ \\
\hline Law & : Land & $\begin{array}{c}:=\text { Moses affirms Yehweh } \\
\text { by negating self }\end{array}$ & $:$ Moses = "Drawer-out" \\
\hline
\end{tabular}

Fig 1.-Paradigmatic structure of the myths of Oedipus and Moses

Constant identity. The hero's unchanging aspect consists of (1) an unusual name, (2) a stigma that is physically manifest as an incapacity, (3) a symbolic function that is implicit in puns on his name and is related to his stigma, and (4) all of which refer to the conditions under which he was born and exposed.

There seems a general consensus that the name "Oedipus" translates well as "Swollen-foot," ${ }^{22}$ and puns as "Know-foot" (from Oida, "I know," and pous, "foot"). His swollen feet give him his disability and he "knows feet." The motivation for this symbolism is the anecdote in which his father, Laios, drives spikes into the infant's feet when exposing him on Mount Citheron.

Turner suggests Oedipus's swollen feet "are the stigmata of his anomalous position in society as the victim of his father's attempt to deny him both his parental connection and his capacity to grow up (effect his passage into manhood)." ${ }^{23}$ Turner, Segal, and Vernant all agree on the relation of this disability and its stigmatization to Oedipus's function in the myth, ${ }^{24}$ that it physically embodies Oedipus's difficulties effecting passages of all sorts, that it can "express metaphorically all forms of behavior which seem unbalanced, deviated, slowed down or blocked." 25

While Oedipus is Swollen-foot, and his name implicitly refers to his functional incapacity to "take (the) proper steps," Moses' physical defect is stigmatized in his speech impediment. Moses is to his tongue as Oedipus is to his feet. Moses' defect is not as explicitly related to his name, but his defect is explicitly linked to his exposure in noncanonic variants. With the same exquisite irony that keeps Oedipus constantly in motion on his swollen feet, Moses, who alone "spoke

\footnotetext{
22 See Turner, "Oedipus: Time and Structure," and "Narrative Structu $\rightarrow$ Michael Carroll, "Lévi-Strauss on the Oedipus Myth: A Reconsideration," American Anthropologist 80 (1978): 805-14; Segal (n. 6 above); Vernant, "Ambiguity and Reversal" (n. 10 above), and "From Oedipus to Periander" (n. 2 above).

23 Turner, "Oedipus: Time and Structure," p. 55.

24 See ibid.; Segal; Vernant, "Ambiguity and Reversal."

25 Vernant, "From Oedipus to Periander," p. 20.
} 
face-to-face" with Yehweh, is charged with constantly promoting Yehweh's word among those who would prefer not to hear it.

The pun on Moses' name is made explicit in the flawed etymology of the E source at Exod. 2:10, where Pharaoh's daughter names the child Moses "because I drew him out of the water." It is widely agreed that the name "Moses" has a close association with the Egyptian root $m s(w)$, meaning "beget," ${ }^{26}$ common in names meaning "the child of (a named god)," or simply "son." ${ }^{27}$ The pun involving the name Moses in Hebrew is on the active form of the verb masheh, which makes the name mean "the one who draws out water," or "the drawer-out." ${ }^{28}$ The problem for the E source was to find a way to give the child a name that implies action at the time the child was still passive and incapable of the action his name implies. This pun on the name Moses is explicitly made in a noncanonic variant in which the Pharoah's daughter calls him Moses because she drew him out of the water and because "he would 'draw' the children of Israel out of the land of Egypt in a day to come." 29

Another noncanonic variant explicitly explains the origin of Moses' stigma as a result of his exposure, ${ }^{30}$ and still another the connection of his speech impediment to his being saved from death at the Pharoah's hand. ${ }^{31}$ In these versions a burned mouth and a violent blow save the child's life. As a child he draws out, through an imperfect speech act, a cry "in a voice like a young man's," the compassion of one who saves him. As an adult in his characteristic function of "the drawer-out," he does not speak when he should but instead delivers a violent blow that saves those depending on him for water in the wilderness. But because he fails to speak when he should,

26 Childs (n. 6 above), p. 7.

27 Gottwald (n. 6 above), p. 194. One problem encountered with regard to names is the supposition of a historical person with that name. Robert Graves, in The Greek Myths (Harmondsworth: Penguin, 1955), 2:13, e.g., aligns Moses and Oedipus along the watery variant of Oedipus's exposure, suggesting "Oedipus" "originally" meant "son of the swelling se $\rightarrow$ Carroll, "A Structuralist Exercise: The Problem of Moses' Name," American Ethnologist 12 (1985): 775-77, assumes "that he [Moses] is called 'Moses' because the historical figure upon whom the legends are based really did (for whatever reason) have an Egyptian name that incorporated the suffix 'moses." Methodologically, "originally" can always only mean "in an earlier variant," never "really." The problem facing the myth is how to name a hero with certain characteristics. That Moses' name has both Hebrew and Egyptian overtones is only as it should be, for one who was both Egyptian and Hebrew.

28 Carroll, "A Structuralist Exercise," pp. 775-77.

29 Louis Ginzberg, The Legends of the Jews (Philadelphia: Jewish Publication Society of America, 1910), 11:207.

30 Ibid., p. 267.

31 Ibid., pp. 272-75. 
Yehweh condemns him to die outside the promised land. ${ }^{32}$ Moses' characteristic function is to "draw out" by speaking, not by violence, and yet it is in this particular activity that his physical defect causes him most difficulty.

Variable identity. In opposition to this name/stigma/function component, which is constant throughout the myth from the earliest episode, is the central episode of the confrontation between the hero and the supernatural being that holds the key to hero's rightful identity. The Sphinx is to Oedipus and the Thebans as Yehweh is to Moses and the Israelites, by inversion of sign, function, and importance in the received tradition. The episode focuses directly on the hero's name, its pun on his function in the myth, and his physical defect. The problem with which the supernatural being confronts the hero demands he solve a hitherto insoluble social problem without directly using force of arms and overcome his specific handicap to do so.

Oedipus, Swollen-foot, must respond to a riddle about human locomotion posed by a creature anomalous in its own mode of locomotion, but the Sphinx's riddle contains no reference to Oedipus's own condition, "one which limps on two." Insofar as Oedipus's feet are related to his knowledge of others' feet, a further pun in Greek relates feet to knowledge in Oedipus's name, "Know-foot."

We know the riddle to have been insoluble because the myth tells us many Thebans died before "Know-foot" limped into Thebes with the knowledge and will to answer the challenge. The answer to the problem confronting Moses is likewise contained in his name and disability: Moses "drew out" the Hebrews from Egypt through the power of words. In the same way that Oedipus's relations to the Sphinx are heavily overdetermined ${ }^{34}$ Moses' objections to his call and the difficulties in separating the Hebrews from Egypt are massively overdetermined. $^{35}$

The hero does overcome his disability at the same time he solves the pressing social problem. Moses negates his previous flawed identity

32 Numbers 20:2-12.

33 Vernant, "Ambiguity and Reversal" (n. 10 above), pp. 96-97; Vernant (ibid., p. 114) cites as well Knox at length on the puns on place and knowledge in Oedipus the King: "Cf. Knox, Oedipus at Thebes, pp. 182-84. On his arrival, the messenger from Corinth asks: Do you know where Oedipus is? As Knox points out, the three lines 924-26 all end with the name of Oedipus together with the interrogative adverb hopou. ... Knox writes: 'These violent puns, suggesting a fantastic conjugation of a verb "to know where" formed from the name of the hero who, as Tiresias told him, does not know where he is (413-14)-this is the ironic laughter of the gods whom Oedipus "excludes" in his search for the truth."

34 See Edmunds, "The Sphinx" (n. 6 above).

35 See Childs (n. 6 above), pp. 66-80 and 121-75. 
in an affirmation of the reality the newly revealed deity presents to him and allows almost his entire identity to be absorbed by this deity. Oedipus, inversely, negates the Sphinx entirely insofar as she hurls herself to her death despite her wings, by affirming all that he himself is not at the most fundamental level of his being.

The minor, mediating, contradiction in the paradigmatic structure is constructed from these materials: a hero constantly identified with a name that is related to his stigma and puns on his primary functional activity in the myth is contradicted by the confrontation of the hero with a supernatural being who returns to him his rightful identity when the hero transcends his constant but flawed identity.

Thus abstracted, the paradigmatic structure of the myth performs its function of mediating a contradiction that cannot be solved by direct confrontation through another contradiction for which resolution seems possible. But while this general representation of the myth's paradigmatic structure and function is clear, interpretation of the "hopeful" aspect of these myths as the myth's "meaning" is insufficient. ${ }^{36}$ These myths both remain utterly clear that personal adjustment, the recovery of one's "rightful identity," is inadequate as a permanent solution. Personal adjustment does not solve social problems, and since all social problems are felt as personal problems, when a problem has genuine social roots, as loss of sovereignty does, personal adjustment will not provide a permanent solution but actively reproduce the problematic situation.

A paradox remains, and that paradox reintegrates the paradigmatic structure with the diachronic time of the narrative structure. The hero as a bundle of invariable properties forced on him at birth is placed in opposition to his own self-transcendence when he recovers his "rightful," yet personally and socially unsatisfactory, identity. Oedipus both is and is not the proper king of Thebes, Moses is and is not the effective leader of the Hebrews. ${ }^{37}$ The hero's solution to his personal problem and the social problem he must face is correct in diachronic time, but not in synchronic time. This is the resolution of the minor contradiction in the paradigmatic structure of the myth, that the "right" answer for one time and place is not the right answer for all times and all places. The myth asserts that sociocultural continuity is possible without sovereignty, but it does not say when, if ever,

36 As Buxton (n. 21 above), p. 36, observes, we cannot assume any particular existence for Oedipus after he departs the grove of the Eumenidies: "But we must beware of convincing ourselves that Oedipus at Colonus ends in a glorious apotheosis. After all, the voice which summons Oedipus is strange, allusive and enigmatic, and gives no inkling of a majestic or godlike existence for him after his death."

${ }^{37}$ See Leach (n. 6 above), pp. 36-37, 59. 
sovereignty will be regained, and it does not say that life without sovereignty will be pleasant.

\section{CONCLUSION}

Jean-Paul Vernant has written that the central problem in the interpretation of myths that have become part of a written tradition is "what is the link between the semantic space revealed by structural analysis of the myth's intellectual framework and the socio-historical context in which the myth was produced." 38 By the beginning of the fourth century B.C., the myths of Oedipus and Moses had converged on a common "intellectual framework" that can be made explicit through structural analysis. This framework consists of three integrated symbolic structures: (1) a narrative that portrays the struggle of the hero as a biography based on his birth and adoption, his recovery of his rightful identity, and his maturity and death; (2) a symbolic structure that clothes this symbolic action in specific images that themselves are arranged to open to reconsideration and reformulation several fundamental categorical relations that found everyday thought; and (3) a paradigmatic structure that portrays a hero in an identity that both changes and does not change.

In asserting that these myths might have been felt by their audiences as relevant to the problem of ethnicity, selfhood, and sovereignty, I have emphasized the importance of the variant fact that both myths record that the specific location of the hero's grave has been forgotten but they do not explain why it was forgotten. All contrary hypotheses that presume this to have been historical fact must further assume a historical hero. ${ }^{39}$ Methodologically, we are not entitled to do so. We have no independent evidence for the existence of the hero. On the contrary, we must understand the "forgetting of the location of the grave" as a component of the myth in its own right, and with a definite relation to the symbolic structure of the rest of the myth.

This partial memory, that the grave is at the margin of center and wilderness in an unspecifiable place, is the cultural analogue to the hero's defect. Limping is to Oedipus as stuttering is to Moses as forgetting is to memory as the loss of the prophet/king's grave is to sovereignty. This "purely formal frame of the mythical armature" 40 (which phrase Vernant attributes to Lévi-Strauss) connecting limping, stuttering, and forgetting can be further related to the reproduction of

38 Vernant, Myth and Society (n. 5 above), p. 239.

${ }^{39}$ Segal (n. 6 above), pp. 482-83.

40 Vernant, Myth and Society, p. 20; Claude Lévi-Strauss, "Myth et Oublie," in Langue, discours societe (Paris: Pour Emile Benveniste, 1975). 
culture in historical societies: the series must include the alteration of texts in reference to the collective memories of societies without sovereignty. Limping is to walking as stuttering is to speaking as forgetting is to remembering as altering texts is to writing history without sovereignty.

The missing terms that fix the myths to their sociohistorical contexts are, first, writing and, second, the preservation of unalterable texts. The myths cannot forget that they have forgotten where the hero is buried because they have written it down and refuse to alter what they have written. The stigma, the physical defect, forced on these societies is "headlessness," the inescapable aspect of their social condition at the time these myths became unalterable texts. It is the knowledge of continued "headlessness," committed to writing, remembered not "in the head" but "outside the head," that allows them to continue as sociocultural entities without "heads."

Of the two myths, the historical context of the Moses myth is perhaps the clearer. The kingdom was divided in 933 B.C. The Assyrians depopulated Israel first (722 B.C.) and then reduced Judah to a vassal state (721 в.C.). Under Josiah, after 621 в.C., the Deuteronomistic reforms were undertaken to reconcile the ritualistic and prophetic strains of the national religion, but political relief was not forthcoming. The Babylonian captivity began in Israel (597 B.C.) and continued into Judah shortly thereafter (586 B.C.). At length Cyrus, as part of his overall policy to resettle conquered peoples in their homelands while retaining political control over them, returned the Israelites to Jerusalem in 538 в.C. Nehemiah rebuilt the city walls early in the fifth century, but the Palestinian community was "no longer politically independent but functioned as an administrative unit within the Persian Empire." ${ }^{41}$ Many separate sources contributed to the written and oral tradition of Israel. The final major contribution that treats the life of Moses, the "P" or "Priestly," tradition, was compiled in Jerusalem circa 450 B.C., and the text that became the final edition of the Pentateuch was compiled, also in Jerusalem, by 400 B.C. ${ }^{42}$

The narrative of a captivity in Egypt and the Mosaic mission offered a rich source of representations to model later experience. But the reestablishment of the Temple in Jerusalem and the large population still in Babylon presented a quandary: what direction should the nation take in the absence of a consolidated population with political sovereignty. ${ }^{43}$ Elsewhere I have examined at length the competing

41 Gottwald (n. 6 above), p. 103.

42 Ibid.

43 See Childs, pp. 316-39; Hengel (n. 4 above). 
claims of the metaphors "land" and "law" in the Moses myth on postexilic Israelite political resources ${ }^{44}$ but without the opposition of the Oedipus myth, it is difficult to proceed to a higher level of generality. The historical context of these myths elaborates the earliest underlying opposition "culture versus nature" into the final opposition "culture versus sovereignty" when sovereignty is lost but a written tradition remains.

The fundamental problem in treating the Oedipus myth in its sociohistorical context is the complex and evolving relations among city-state politics, earlier kin-based social relations, slavery, warfare, and the classical Greek conception of power. It is necessary to examine these relations in general rather than focus exclusively on the details of political events because myths are not produced in response to specific historical events, even though plays may be, but are altered to interpret and make sense of the general stream of experience. ${ }^{45}$

The sociohistorical context of the Oedipus myth in the fifth and fourth centuries B.C. is primarily Athenian. However we understand this myth, its most complete version is that of Sophocles, who was and wrote as an Athenian. There is now no way we can distinguish between the version on which Sophocles founded his plays and the myth's expression in his plays.

The pervasive structure of reversal that Vernant identifies in Oedipus the King generally describes Athenian political fortunes in the fifth century. Athens's role in the victory over Persia and its remarkable achievements before and under Pericles "contributed to the feeling that Athens was the centre of the world, there to teach others." 46 During this period of self-conscious cultural advance, Oedipus became intelligent and the riddling episode became the favorite of the Athenians. ${ }^{47}$

But DeSelincourt asserts that even by the time of Pericles "the best had already passed." ${ }^{48}$ Muir suggests more specifically that by the last quarter of the fifth century there was in Athenian consciousness "a panic nostalgia for a more controllable, safe and stable world" as the result of losses from plague and continued warfare. ${ }^{49}$ DeSelincourt

$\rightarrow$ Robert C. Marshall, "Heroes and Hebrews: The Priest in the Promised Land," American Ethnologist 6 (1980): 772-90.

45 Sperber (n. 7 above), p. 145.

$46 \mathrm{~J}$. V. Muir, "Religion and the New Education: The Challenge of the Sophists," in Greek Religion and Society, ed. P. E. Easterly and J. V. Muir (Cambridge: Cambridge University Press, 1985), p. 192.

47 Edmunds, "The Sphinx"(n. 6 above), pp. 160-61.

48 Aubrey DeSelincourt, The World of Herodotus (Boston: Little, Brown, 1962), p. 367.

49 Muir, pp. 191-92. 
remarks that Athens's inability to organize an empire "prepared her own destruction; and with the death of Athens as a political power, ... the essential spirit of Greece died too." 50

Vernant is explicit on the role of warfare in the transformation of the city-state in classical Greece, on what arose after Homer and perished with Athens's defeat. Warfare, earlier the private occupation of an elite warrior class, became the responsibility of the city-state as a whole through the elevation of all its citizens to the status of elite warrior. ${ }^{51}$ This process required the deliberate leveling of social hierarchy in the city social structure, ${ }^{52}$ which only the most limpid distinction between slave and citizen could make possible. Citizens were "free," and slaves were not. The citizen should not labor, but govern. ${ }^{53}$ Power politics became the very reason for being of the city-state; its economic functions were minimized. In this setting, power was largely conceived as force, coercion, violence, and no longer the possession of some and not other citizens. The exercise of power in war as the collective responsibility of its citizens made city-state culture possible. ${ }^{54}$ Alphabetic writing and city festivals continued as the primary means of wide dissemination of this culture. ${ }^{55}$

Warfare under earlier conditions did not mean the utter destruction of the opponent; rather, it took "the form of an organized competition which rules out the fight to the death to annihilate the enemy as a social and religious being, and conquest designed to absorb him totally." 56 But this system of rules of war gave way during the Peloponnesian War: "Even before it the balance was necessarily an uneasy one; it rested on the tension between the will to leadership of the various states and the ideal of self-sufficiency which no city could renounce without denying its very nature." ${ }^{57}$

It was this interrelation of culture and politics, both dependent on the sovereignty of the city, itself a function of the power to coerce, the capacity to sustain war, that Athens lost in 403 B.C. and which was

50 DeSelincourt, p. 367.

51 Vernant, Myth and Society, p. 41.

52 Ibid., p. 83.

53 Perry Anderson, Passages from Antiquity to Feudalism (London: Verso, 1974), p. 23. It is perhaps worth considering whether the conflict in the Oedipus myth represented by "kinship" and "polity" as identified by both structuralist and nonstructuralist commentators might not have emerged in Greek consciousness with regard to the form of social organization best suited to the exploitation of slavery in a primarily agricultural setting.

54 Vernant, Myth and Society, p. 83.

55 See Jack Goody, The Domestication of the Savage Mind (Cambridge: Cambridge University Press, 1977); and Havelock (n. 5 above).

56 Vernant, Myth and Society, p. 31.

57 Ibid., p. 33. 
completely obliterated by Hellenistic warfare ${ }^{58}$ It was not necessary to wait for the rise of Philip and Alexander to know that something else had been definitely lost, perhaps permanently, with the fleet at Syracuse. ${ }^{59}$

The contradictions of power and culture these myths model would have been experienced on all dimensions these myths encode: status and ethnicity, geography, identity and behavior, religion and family life, representations of the past in the present, the politics of domination, and the culture of politics. These myths recommend the reconstruction of centers become wildernesses to the power of other centers as permanent cultures, forms of power in which the knowledge of the preserved word is paramount. Athens and Jerusalem were the same cities they had been, and they were not. I do not suggest that these myths by themselves effected this transformation, nor that I have examined, even superficially, all of the codes in which experience is represented in these myths. ${ }^{60}$ But I do suggest that these myths were structured under the above conditions in the forms in which they were preserved from the beginning of the fourth century and that the writing down and preservation of these myths in unalterable forms was ineluctably bound to this historical transformation.

\section{Western Washington University}

58 Ibid., pp. 33-34.

59 DeSelincourt, p. 396.

60 See, e.g., Vernant, "Ambiguity and Reversal" (n. 10 above); $\rightarrow$ Dorothy Willner, "The Oedipus Complex, Antigone and Electra: The Woman as Hero and Victim," American Anthropologist 84 (1982): 58-78, for recent discussions of the sexual code in the Oedipus myth. 